\title{
Museum BUILDings AND THEIR FUNCTIONS
}

\author{
Ase Enerstvedt
}

The most beautiful museum building in Scotland-perhaps even in the world - was opened in Edinburgh at the end of 1998. The exterior is breathtaking - marble and sandstone in shades of pale rose and yellow, with a smooth surface that challenges the tactile sense of the passers-by. The Museum of Scotland is situated in a busy street, surrounded by important historical buildings. A modern building on this site could be a disaster, but though the museum is extremely modern in style, it harmonizes to the extent that it is experienced as a natural part of the existing architecture in the surrounding streets.

The building has its critics. It is new, different, with an artistic style which some people find incomprehensible. The bright colours and the big windows stand out from the surroundings, and the protruding parts of the building - like drawers that someone has forgot to shut - are strange and might seem "untidy». But the general impression is that the building has its natural place in the street. I would not be surprised if within few years people regard the museum as «always» having been there.

Scotland gets its own parliament in 1999, and it is surely not mere chance that the new Museum of Scotland has just been completed. It is an obvious symbol of the Scottish nation, pointing back in history as well as forward into the new millennium. Its resemblance to a castle makes it "the millennium Edinburgh Castle» - not set high on a crag, but in the middle of a busy city. Even in that way it is a symbol of the urban lifestyle which characterises the world on the threshold of the 21st Century.
The entrance to the new museum is in a round tower where one easily can imagine the door is a drawbridge and the narrow vertical and horizontal slits in the walls are embrasures.

The slits are repeated in the interior walls. As the visitors are led from the round tower into the museum's main hall, the impression of a castle is strengthened in a corridor, which is rather narrow but reaches almost to the top of the building. It is as if, having passed the outer wall, one were walking at the bottom of a moat 
Ase EnerstVedT

trying to enter the main part of the castle.

Entering into the main hall, the visitor has only reached as far as the court-yard. It is enormous, white, and extends straight up to the ceiling. The whole entrance, including the exterior of the tower, the moat and the court-yard symbolises that this building is guarding the history of Scotland. The impression is both martial and sacred. Access to the "palace» within the walls of the castle, is through several openings in the walls. As in medieval castles, the stairs are hidden behind thick walls, and there are no doors, only "gatevaults». In different places there are observation posts on the high wall, from which people look down into the court-yard.

The visitor must be utterly insensitive not to feel that he or she is in an honoured position, on the point of being admitted to the treasures of Scotland.

\section{KINGDOM AND CHURCH}

And that is exactly what happens. A huge stone cross with carvings showing King Constantine who is known to have lived in the early ninth century, draws the attention as the only decoration in the great, white hall. Behind the stone cross is a room - a gate-vault - with words written as decorations on the walls, and builtin showcases. We understand that the cross symbolises the beginning of the Kingdom of the Scots, and this is really the entrance to a treasure room. The words on the walls, from The Declaration of Arbroath in 1320, tell us that "As long as only one hundred of us remain alive, we will never under any conditions be brought under English rule» and "For we fight not for glory, nor riches, nor honours, but for freedom alone which no good man gives up except with his life.» The long list of kings' names following these words, makes it easy to convey the impression of entering the king's palace. Though the pre-Christian period is not far away - a time which can be studied in the basement - here we are not allowed to forget that the Kingdom of Scotland was a Christian kingdom. The stone cross outside the gate and the glass box in the middle of the floor, containing a beautiful reliquary from circa 800 , carry the message.

Inside the "gate" the architect has continued the medieval castle motif along the left side of the hall, while the right is predominantly Renaissance in style. From an aesthetic point of view, the two parts of the room harmonize, with dark brown wooden objects along the walls and the middle of the floor, with showcases containing silver, and with a gentle illumination carefully calling attention to the objects.

The labels on the walls and in the montres are modest and do not disturb the display. The two different types of lettering allow the reader to choose how much time he/she will spend reading. The visitors however seemed to miss labels which could give them a little help in finding their way through the museum. Of course, the beautiful printed guide which one can buy in the shop is a great help. But very few visitors were seen walking around with the guide in their hands. The Museum even has headphones and sound tapes to help the visitors, which seemed to be very popular. 


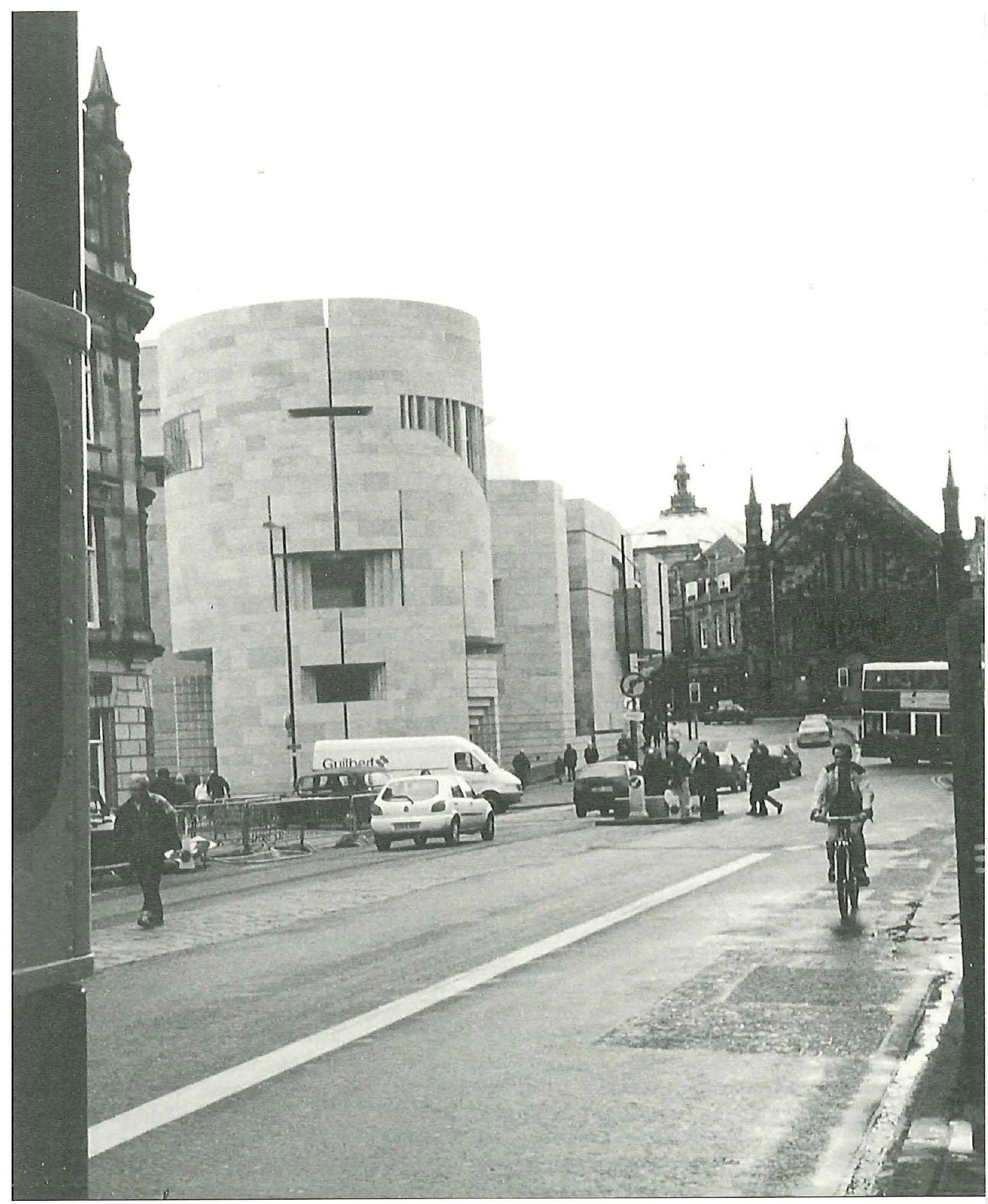

The Museum of Scotland is situated in a busy street, surrounded by important historical buildings. A modern building on this site could be a disaster, but though the museum is extremely modern in style, it harmonizes to the extent that it is experienced as a natural part of the existing architecture in the surrounding streets. Photo: Ase Enerstvedt. 


\section{TREASURES AND UTILITIES}

What kind of objects do we meet in "the millennium castle»? And what story do they tell the visitors? To take the last question first: The story the objects tell, depends on who is looking at them. We all bring our own references, our own intentions, our own attitudes. To some this is the story of a brave nation, few in numbers, but with many outstanding personalities and afflicted from the beginning by wars, enemy attacks and internal conflicts. The many relics of kings, battles and treaties add fuel to this way of understanding the story.

To others, it is the story of a nation with a will to survive, creative, sometimes showing genius, farsighted and in the forefront of the industrial revolution. The big steam pumping engine built in the central room of the exhibition premises, together with the many tools, from hand tools to steam driven machines, are proof of this story.

Some visitors only look for the treasures, regardless of the context in which they existed, or in the context in which they are displayed in the museum. These visitors will be very happy with the new Museum of Scotland. Here, beautiful glass and crystal, jewellery, paintings and sculptures of important people are displayed. But it is not primarily telling the story of kings and queens, the church and the top ranks of society. The exhibitions tell the story of the nation as a whole, the story of a people who this year for the first time since 1707 will vote for its own parlia- ment. We can read the story of people working in commerce, farming, and craftsmanship of every kind. Less is told about the household, the life of women, children and the old. But, experience tells us that this is due to the lack of objects which have survived, not to the idea behind the exhibition.

\section{A MUSEUM HISTORY}

It is time to open a discussion on this latest Scottish contribution to the museum world. The museum in itself is not new. It was founded in 1781 with the improving of craftsmanship as one of its aims. Four important and well established museums dating from the beginning of the 19 th century were already contributing to the fulfilment of this aim. The four are the National Gallery containing national and international works of art up to the impressionists; the Portrait Gallery, opened in 1881; the Museum of Modern Art and the Royal Museum of Scotland. This last museum contained a natural history collection and the collection that has now been moved into the New Museum of Scotland. The two buildings now housing these two collections are, however, connected to each other, and administered by the same management. Thus the exhibitions although in two buildings might be seen as parts of a whole.

This is not the place to discuss the old museum building. Possibly it was extremely difficult to create exhibitions there even when it was built in the 1850's. And the difficulties have surely not faded as times 


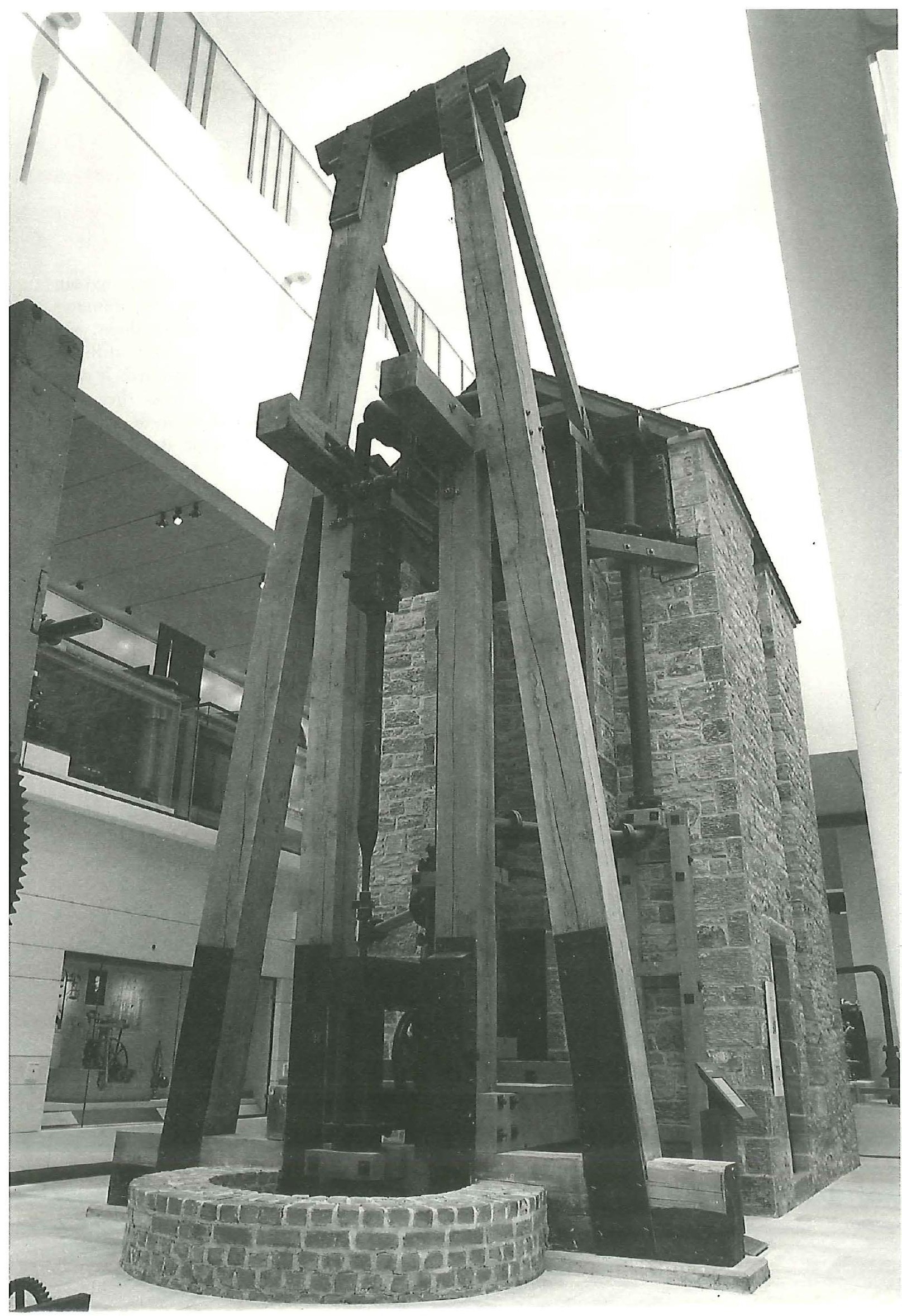


ÅsE ENERSTVEDT

28 have changed and new methods and new demands have come into existence. But what is important today is how the work of the museum, the idea of the museum, are regarded and reacted to by people who occasionally come into contact with this side of cultural work.

Architects as a group of professionals have the opportunity to gain a deeper understanding of this aspect of museum work, how things are done, what norms and what aims govern the museums. When an architect has been given the task of designing a museum building, we know that a co-operative project is normally started. A team made up of members of the museum, other groups with an interest in the project, and the architects meet continually to discuss the project during its progress.

Why is it then, that again and again we find that strangely the function of the building has been neglected? In some places the neglect is obvious, in other places it manifests itself in small details, but it is in daily conflict with the people who work there. Are museum people too weak, too unfocussed in their demands, unable to express their knowledge of their own work and not really sure of what they need?

I do not believe that this is the case. I am afraid that those who are to blame for the failure are the architects. Once acquainted with the ideas and concepts of their clients, they prefer to continue on their own. Details about the functions, about the work which has to be done in the building many years after opening day, are of little interest. What characterises architectural work seems to be its superfluous attitudes. The architects are meticulously occupied with the material and the way the material looks. They are completely taken up with the measurements, with the ideas of lights and shadows, with the view of the building from different angles, both external and internal. It is the visual expression in the lines they have drawn, the colours they have arranged between these lines, that interest them, and sometimes they give the impression that they would prefer the buildings never to be used for any other activity than to be viewed.

My personal problem is that I understand them. I love buildings under construction and I love empty rooms - in the same way as I love an empty white page of paper and an empty white painter's canvas. They are perfect in their whiteness and in the infinite number of their possibilities. Nothing disturbs. The same applies to an empty room with a clean wall. Especially if the walls dimensions are designed in such a way that the wall in itself is a work of art. In the Museum of Scotland, the architects have placed slits of different shapes and different dimensions in every wall. The intention is that the visitors should look through the slits at the many rooms, and constantly meet new and different views of those rooms. Beautiful and interesting when the room is empty. But what happens when the objects are on display? First of all, they ruin the impression of the clean wall, they disturb the open space. Instead of meeting a different shade of white wall, you see an object which might have the most discordant shape and colour. Then, the object might have been placed on the wall in a way that disturbs the effect of the slits which are placed in a certain relationship to each other. Conditions are changed, 
and like a painter who cannot let another paint on top of his work, the architect experiences despair.

To arrange an exhibition is no less artistically creative than designing a building. Consider the people who, because of their knowledge and the aims for which they are appointed, have to create an exhibition within the frames that the building sets! Their work and artistic ambitions are limited both by the building and the different objects they have to put on display. Anyone who is given a task by someone, has to work within limits. In the Museum of Scotland, the visitor can discover some places where the staff must have met with obstacles which they have sometimes been unable to overcome and faced with an overwhelming architecture they have had to yield to. The exhibition as a whole, the specific object and the building have all been the losers from this. One example is the church collection on the ground floor/first floor. The church benches give the impression of being in a storehouse. Displayed like this, they are just any brown, wooden church benches. The way an object is displayed is immensely important, and even if these benches are of specific importance in Scottish history, they still look like any other wooden benches that have been stored away. An almost similar thing has happened to the beautiful church wall - a wooden carved screen that once divided the nave and the choir in a Scottish church. It is placed in the same narrow space as the benches and no onlooker today can understand the overwhelming impression this wall must once have made on the people attending mass, who saw it from the big open space in the church.
In the Museum of Scotland the visitor experiences the space and the walls and the objects in his own way. He soon discovers the slits, and most visitors think they are interesting and even fun. Few people have said that they have experienced them from the aesthetic point of view. Every room has its measure of slits and everywhere the visitor is allowed to see through slits into other rooms, near and far. You feel that people are passing by the slits under you, on the same level, or high above you. Heads pop up behind you, beside you, people walk over bridges high up in the air, and they put their heads through a slit beside the object which has caught your interest at the moment.

The noise from all these people ascends towards the ceiling, high above their heads. It starts at the entrance door in the round tower, creeps along the stone walls in the "moat", grows among the people standing on the pavement in the courtyard, continues up the stairs and into the rooms on every floor, meeting other sounds, thrown from wall to wall in the big hall, and ends up as a roar on the fifth floor - the place reserved for the 20th century exhibition. There is not one door, not one possible place to think or talk in peace. The guides have to shout to be heard, and as there is more than one guided group at any one time, there are usually more than one voice trying to overcome the noise. In addition to this, the loudspeakers - as it seems every third minute - broadcast messages to the visitors, making it impossible even to hear one's own voice. But that is not the fault of the architects! 


\section{THE DILEMMA}

Finding that a kind of evolutionist principle has been followed in placing the prehistory in the basement and the 20th century at the top of the building, made me feel that the architects and the curators must have been on two very different levels during the planning. To what extent have the architects' ideas influenced the exhibitions? How often have the curators had to give in to the architects' demand to be free to develop their aesthetic ideas and their right to fulfil their own artistic ambitions? When the public do not find what they are looking for, or find that what they think as important is neglected, they blame the museum staff. No excuses about the architecture will be accepted, because the general view is that the building is a frame, and what is inside is the responsibility of the people who work there.

There must be more than one reaction to the new Museum of Scotland. Some claim that the building in itself is important. It is also an object that tells us about the history of Scotland. I can agree with that view, but is it the only one? Is it right that the building should suppress all the other objects which are inside it? This suppression is not due to the beauty and importance of the building. We have seen many examples of mediocre buildings which have been just as suppressive as this one. The answer lies in that the architects were just as sure of their rights to express their art undisturbed by the users.

The curators must have had a difficult job making the exhibitions fit into these architectural frames. Seen from the exposition side, the ideal room is a big hall without colour, without windows and without any characteristics at all. From this "tabula rasa" the creation can develop. The more restrictive the frames the building imposes on the professionals, the more difficulties they have to fight against.

Perhaps the average visitor never thinks about any of the negative aspects which I have pointed out here. Perhaps this is a «behind the scenes» problem. Yet - perhaps the visitors would be even more gratified if the architecture and the functions were more in harmony?

Ase Enerstvedt er frilance fagbokforfatter med magistergrad i etnologi. Har arbeidet $i$ norske museer siden 1960-tallet.

Adr: Drammensveien 975, N-1370 Asker

E-post: ase.enerstvedt@eunet.no 